\title{
Economic Impact of the Ministry of Defence's Budget: Methodological Design and Results for the Spanish Economy
}

José R. García, Joaquín Murillo, Jordi Suriñach and Esther Vayá

AQR Research Group-Research Institute of Applied Economics. University of Barcelona, Avda Diagonal, 690, Barcelona, 08034, Spain

\begin{abstract}
This article analyses the economic impact of the expenditure budget of the Spanish Ministry of Defence (MoD) and its Autonomous Agencies (AA), distinguishing direct, indirect and induced effects. The input-output methodology is used to find intersectoral effects on the rest of the economy. The article quantifies the economic impact in terms of production, gross value added (GVA), employed population, tax revenue, and also in terms of its contribution to the gross domestic product (GDP) of Spain in 2010. The results show that the activity of the MoD and AA generates $1.2 \%$ of the country's GDP and $1.7 \%$ of total employment in that year.
\end{abstract}

Keywords: economic impact, analysis of defence budget, input-output methodology, direct effects, indirect effects, induced effects

\section{JEL Classification:}

C67, E60, H50 


\section{Introduction}

The objective of a state's defence sector and armed forces is to prevent any external agent - whether another state, some organization or terrorist group - imposing its will by use of force (Hartley, 2010).

The benefits associated with maintaining that security are very difficult to calculate (Martí-Sempere, 2011), and are not quantifiable in monetary terms, because these benefits are due mainly to savings from potential threats avoided. However, it is possible to quantify the costs of maintaining such security. The existence of the armed forces (and the general defence policy of a country) is comparable to an insurance policy: you buy into it in anticipation of a contingency that, perhaps, never occurs, and (if it is ever to happen) its economic effects are not known a priori. On the other hand, the annual cost of the insurance policy can be approximated quite accurately.

Defence policy and economy, broadly defined, are interrelated. ${ }^{1}$ Adam Smith, in his Inquiry into the Nature and Causes of the Wealth of Nations, stated that one of the functions of the state was to 'protect society from the violence and invasion of other independent societies', while security is integral to progress.

In recent years several authors, such as Chan and Clark (1990), Dunne et al. (2005), Heo and Hahm (2006), Erdogdu (2008), Feridun et al. (2011) and Wanga et al. (2012), among others, mention defence spending as a key factor in preserving the functioning of markets and encouraging investment and innovation, laying the groundwork for a global environment of trade opportunities, insofar as this expenditure ensures the safety of

\footnotetext{
${ }^{1}$ An interrelationship that is not always unambiguous (see, for example, Safdari et al., 2011). Defence spending has effects on the economy as a whole, but the current economic cycle also affects spending on the defence of the moment.
} 
persons and property. Moreover, where there is a perceived lack of security in an area, the economic activity in that territory is hampered, for example discouraging potential investments. Feridun and Sezgin (2008) exemplified various regions affected by the existence of terrorist groups and/or guerrillas: south-eastern Turkey, the Basque country, Sri Lanka and the island of Mindanao (Philippines).

The existing international literature, which deals with the economic effects of defence spending, suggests several ways in which this can influence production, in particular and in general regarding the economy. Dunne et al. (2005) state that these effects can be structured into three categories: safety, demand, and supply. Dunne and Uye (2010) argue that defence spending may have an impact on the economy through its effect on the labour market, savings and investment, aggregate demand, technological development, public debt, international relationships, socio-political conditions, etc.

Moreover, various authors, such as Cowan and Webel (2005), EPS (2007), Andersson et al. (2007), Thanner and Segal (2008), Paloyo et al. (2010), Cowan and Gonzales (2011), and Hultquist and Petras (2012), analysed the effects of defence spending on the economy in an environment of spending cuts. In other studies, the impact that activities or facilities for defence have on the local economy, mainly arising from the existence of military installations, are analysed (Brockett et al., 2004; Schauer et al., 2004a and 2004b; Sommers, 2004; Stehlik et al., 2004; Weinstein and Clower, 2004; Soden et al., 2005; Nivin and Birdwell, 2006; BBPC, 2009; Bernauer et al., 2009; Hill, 2009; Hunter, 2009; Chiappe, 2011; Hamsik and Moore, 2011). 
Another line of existing research is that which analyses the relationship between defence spending and economic growth through econometric modelling, with items that show a positive or negative relationship, with no consensus on this, as documented by Smith (2000), Dunne and Uye (2010), Heo (2010), Wijeweera and Webb (2011), Alptekin and Levine (2012), or Dunne and Tian (2013), among others.

The present study uses another approach, complementary to the previous ones, since its objective is not to contribute to the current debate on the relationship between defence spending and economic development, but rather to determine the magnitude of the resultant effect of all the activities implemented by the Ministry of Defence (MoD) and its Autonomous Agencies (AA) ${ }^{2}$ on the Spanish economy in $2010 .{ }^{3}$ We do not intend to make a counterfactual study or analyse what is the optimum level of defence spending. Our aim is to identify and quantify the size of the MoD as an operator that intervenes in our economy, i.e. measuring the economic impact of the activity carried out by the Ministry and its AA.

This analysis, carried out for 2010, is particularly important in a time of crisis in which there is a need to reduce public spending, particularly in certain departments such as MoD. For example, in Spain, from 2008 to 2011, military spending reduced its weight on GDP by $0.16 \%$, compared with growth in education $(0.39 \%)$, health $(0.41 \%)$ and $\mathrm{R} \& \mathrm{D}(0.04 \%)$. Our interest in knowing the level of economic impact associated with the MoD budget has sense by itself. The aim is to present the defence budget to draw conclusions about the contribution of the MoD in the Spanish economy. This provides

\footnotetext{
2 The Autonomous Agencies (AA) are: 'Esteban Terradas' National Aerospace Technical Institute, El Pardo Experiences Hydrodynamic Channel, The Institute of Housing, Infrastructure and Equipment of Defence, the Military Service of Construction, the Horse Breeding Body of the Armed Forces, the Social Institute of the Armed Forces and the National Intelligence Centre (CNI).

${ }^{3}$ This study focuses on the activities of the MoD and AA; for that reason, it must be noted that it does not include the evaluation of the military industry sector, except in cases where the activity of the Ministry interacts with it.
} 
unknown information to specialists and the general public so that they get to know the full extent of its contribution.

To calculate this impact, the article does not focus exclusively on activities that are usually related to military spending, but also considers those resulting from other complementary activities funded by the Ministry, such as those related to financial and tax administration, culture, health or R\&D\&I. This guarantees full consideration of all defence policy activities determined by the government and management of military administration.

In short, this study aims to answer questions such as: What is the volume of the economic effect generated in the whole of Spain as a result of the activity of the MoD? Which sectors of Spanish economic activity benefit from economic flows generated? What economic relevance do these activities have throughout the Spanish economy? We estimate the economic impact in 2010 in terms of turnover, gross value added (GVA), employed population and tax revenues associated with different activities both by the central bodies of the Ministry and the Armed Forces and, finally, by its Autonomous Agencies. The results are presented in a comprehensive manner, although they are produced individually for each organ of the military. The details are available to the reader on request.

The methodology considers not only the direct effects on the economy, but also the indirect effects, taking into account the MoD and AA as consumers of goods and services from other economic sectors, so that the activity of these generates a multiplier 
effect on the whole economy. In addition, we estimate the induced effect that creates additional demand for goods and services, benefiting the whole economy.

Before continuing, it should be noted that the economic impact figures presented cannot be considered as total 'figures' of the impact of the activities of the MoD on the Spanish economy, but only those that are susceptible to recognition and quantification from the MoD budget data and financial statements of its AA (called 'tangible measurable effects' from the analysis of the MoD as an economic agent). However, there is another set of economic activities that are very difficult to quantify (and which would require a specific study for each of them), such as the economic consequences of the training of the military for civilian life, or foreign investment made in Spain given the security and stability that exists, which, although tangible, we cannot quantify in the absence of sufficient statistical information. Also, there are intangible effects that cannot be quantified in monetary terms (especially social and cultural effects associated with the armed forces), which are not the subject of this article.

It would be interesting to compare our results with those from other countries. However, to our knowledge there is no similar work regarding the expenditure of defence budgets that distinguishes direct, indirect and induced effects. Therefore, this article is the first to quantify the multiplier effects that the budget of a Ministry of Defence has on the main macroeconomic variables, and also its diffusion effect in other economic sectors.

The paper is structured as follows. This introduction is followed by a detailed presentation of the methodology used. Then the set of results is presented, distinguishing between different types of impacts considered, including production, 
GVA, employed population and tax revenue. Finally, the main results are summarized and conclusions are drawn.

\section{Methodology and Statistical Information}

This section presents the methodological framework used to achieve the objective of quantifying the economic impact posed and the main sources of statistical information used.

The main agent of analysis is the Spanish MoD, Department of General Administration of the State, which conducts the preparation, development and implementation of the defence policy determined by the government and the management of military administration. Defence policy, in short, is that which determines the objectives of national defence and the resources and actions needed to obtain them, integrating into the international context through participation in international organizations, peace operations, and linking to various treaties. In developing its activities and achieving a defence policy, the MoD not only generates economic and social effects (tangible and intangible) but also cultural effects (Figure 1).

[Figure 1 near here]

\section{Type of Economic Effects}

To analyse the economic impact of the MoD and its AA we distinguish three types of effects: direct, indirect and induced.

When the economic impact of an infrastructure, or an investment or activity conducted by an operator (a company, a public institution or, as in this case, the MoD and its AA) 
is analysed, this should not only include its direct impact in terms of production, GVA or employment. On the contrary, the MoD's (and its AA's) need to purchase goods and services and perform various investments leads to an increase in the activity and employment of the sector providers of such products. In turn, such providers may respond by making increasing demands for other goods and services provided by other sectors, and so on. Thus, as a result of the initial pulse application by the MoD and its AA, a complex web of intersectoral relations is triggered, which translates to a multiplier effect on all sectors of the economy (indirect effect). The economic impact, however, does not stop at the direct and indirect impact. In a second phase, so-called induced effects appear, derived from that part of workers' income that is intended to be used both directly and indirectly for the consumption of goods and services in the country. Therefore, the estimation of the economic impact coming from the activity of the MoD and its AA should consider, in aggregate terms, all three types of effects: direct, indirect and induced.

Direct effects are derived from the MoD's own activity and that of its AA. Both perform various activities carried out by themselves, which require the employment of personnel (remunerated by wages) plus the acquisition of supplies of various kinds. According to the code of economic classification included in the Spanish state budget, expenditures are classified as those resulting from current operations, ${ }^{4}$ capital transactions and, finally, financial operations. ${ }^{5}$ The total items included in the budget are the initial expenditure, and are embodied in the GVA and in the number of direct employees generated by each entity.

\footnotetext{
${ }^{4}$ These include: staff costs; current expenditure on goods and services; the interest burden of all types of debts incurred or assumed; and finally conditional payments of the receiving agents, including in-kind subsidies.

${ }^{5}$ This covers loans for the acquisition of financial assets that can be represented in securities, account annotations, etc., as the amortization of debt issued, incurred or assumed by the state or AA.
} 
Indirect effects are classified as first and second order. First-order indirect effects are those that originate in the initial impulse of $\mathrm{MoD}$ and AA spending on the aggregate demand of different economic sectors. These effects are embodied in current expenditures that are necessary to carry out their activity.

All these components of expenditure result in an increased production of all sectors acting as suppliers, with a subsequent increase in the employment and GVA generated by them. Furthermore, this indirect effect is not limited to the impact produced in the first instance. In turn, companies supplying the MoD and AA require other goods and services to carry out their production. Therefore, the initial increase in demand from the suppliers of MoD and AA has a multiplier effect on other sectors of the economy. This is the second-order indirect effect.

Finally, we consider the induced effect, which occurs at a later stage. This effect captures the economic impact resulting from the portion of the income earned by workers that is intended for the consumption of goods and services in the country. Thus, both the direct employees of $\mathrm{MoD}$ and $\mathrm{AA}$ and the indirect employees demand goods and services in the country. This consumption leads to increased production, GVA and employment. In turn, this increase is multiplied when the various sectoral relations come into play in the economy. Therefore, the spending of income earned by workers of the MoD and AA produces an induced effect in terms of GVA and employment.

[Figure 2 near here] 
This methodology measures total economic impact and assumes that these effects do not occur in the same time frame (Figure 2), but are sequential. So, direct and indirect effects are reflected in the short and medium term. However, induced effects appear later and these are the effects that are caused by the stimulus transmitted to the economy by the consumption made possible by the labour income generated, either directly or indirectly, by MoD and AA activities.

\section{Methodology Used to Quantify the Direct Economic Effect}

To determine the direct effect, we use as our primary data resource the public collection in the budgets of MoD and AA, but also consider information from the accounts of commercial operations of the AA, since the latter captures the business made by some of these organs. ${ }^{6}$

The diversity of the data, both in nature and in volume, implies that, given the need to use information on a proven and fully consolidated basis, the same reference period, 2010 , is used.

In the characterization of budget expenditure we have evaluated all and each of the subconcepts that appear in the MoD and AA budget.

Special attention has also been made to the eradication of possible over-sizing, which may result from the double counting of some of the budget or full consideration of some effect items that cannot be attributed exclusively to the agent tested.

\footnotetext{
${ }^{6}$ For example, the Military Service of Construction or the National Institute for Aerospace Technology
} 
From this information we proceeded to compute the direct effect of the activity carried out by the MoD and AA in terms of both production and GVA (sum of compensation of employees and gross operating surplus and number of employees).

\section{Methodology Used to Quantify the Indirect Economic Effect}

After estimating the direct effect, it should be considered that the MoD and AA, in order to carry out their activities, have to acquire goods and services and, therefore, these institutions demand inputs from various companies, generating what we call first-order indirect effects. The analysis of consumption is crucial in order to know which sectors the economic impulse is transmitted to.

Thus, once the structure of expenditure from the MoD budget 2010 was determined, we used the information relating to payments made in 2010 that is provided in the settlement of state budget 2010. The combined use of the two sources of information described has yielded estimates of first-order indirect economic effect. In the case of AA account information, economic-patrimonial results were used, in which the profit or loss (surplus or deficit) is collected, properly separating the income and expenses attributable to it. Thus, inclusion of expenditure under the trade is guaranteed in the analysis. Again, the identification and quantification of the expenditure structure, both administrative and commercial, make it possible to obtain estimates of the indirect economic effect.

It is important to note that this calculation of first-order indirect effect excluded all items of expenditure incurred outside the country (i.e. purchase of goods and services 
from suppliers located abroad) since these imports would not generate an economic impact on the Spanish economy.

In addition, it should be noted that this first effect on aggregate demand is transmitted from the consumed inputs in the production of these activities, giving rise to what is known as an indirect effect of the second order. Thus, the effect is not limited to the indirect impact caused in the first instance. It generates a second indirect impact that affects a wide range of sectors through intersectoral linkages that occur among the companies affected by the first impact, as a result of the needs of production. For example, one of the sectors that satisfy the demand of the MoD and its AA is the textile industry (with provision of military uniforms to the armed forces). This first-order indirect effect generates a new demand for goods and a range of services, such as buying fabrics, machinery for processing, dyes processing, etc. Hence, the initial increase in aggregate demand comprises a second round of economic flows beyond the sectors initially covered by the demand for MoD and AA and constitutes a linkage effect on the rest of the economy.

In order to estimate these effects (in terms of production, gross value added and employment) we use the input-output methodology and the Symmetric Input-Output Table (TSIO, 2005) of the Spanish Economy. ${ }^{7}$ The input-output methodology has been widely used in economic impact studies to determine the additional effect on the economy of direct impact. Its application is also widespread among the studies that aim to determine the economic impact caused by the activity of various components of the defence sector. This includes, among others, AMEC (2004), Lahr (2004), Sommers

\footnotetext{
${ }^{7}$ The TSIO 2005 provides a breakdown of 73 branches of homogeneous activities. Therefore, we have had to relate the TSIO codes with the expenditure distribution based on NACE codes (European Classification of Economic Activities)
} 
(2004), Maguire Company and ESI Corporation (2008), Nienow et al. (2008), Nijhawan and Jackson (2008), Deloitte Touche Tohmatsu Ltd. (2012), Jaffry et al. (2012) and KPMG (2012).

\section{Methodology Used to Quantify the Induced Economic Effect}

The induced economic effects are caused by increased production in the country due to the increase of demand generated by the growth in employment (directly or indirectly originated by MoD and AA). The income of these employees is intended for the consumption of goods and services.

In order to estimate the induced effect we use the compensation of employees generated directly and indirectly and subtract their contributions and deductions for social security, and the costs incurred outside the country as well as the savings component. For this we used information from the decomposition of gross salary provided by the National Statistics Institute (INE) from the Wage Structure Survey Data and data provided by INE in Quarterly National Accounts of Spain. Secondly, once the net labour income that workers earmark to use for consumption has been estimated, we distribute such income at the sectoral level following the sectoral distribution of private household consumption according to TSIO. Finally, the input-output methodology is used to estimate the effects of this consumption in terms of employment and GVA.

In this regard, it should be noted that this impact benefits all sectors of the economy. This is due to two reasons: first, the workers, as consumers, acquire all kinds of goods and services; and second, in order to meet the demand for such products, the entire set of intersectoral relationships in the Spanish economy is activated. 


\section{Methodology Used to Estimate the Total Economic Impact}

Once the direct, indirect (first and second order) and induced effects have been estimated, we can proceed to the calculation of the total effects as the sum of the previous three in terms of production, GVA, employment and tax revenues. To obtain an estimate of the tax effect we apply the average effective rate of each tax provided by the Ministry of Economy and Finance. In this way, the methodology used to estimate the final economic impact is based on the completion of a series of intermediate objectives that are addressed sequentially in the three stages shown in Figure 3.

[Figure 3 near here]

\section{Results}

The results of the direct, indirect (first and second order) and induced impacts are presented below. Finally an estimation of the tax revenues from corporate tax, value added tax, and income tax of individuals is displayed.

Table 1 lists information on the direct impact of the different organs of the MoD and its AA. The MoD and AA generated directly production of 9,359 million euros and a GVA of 5,036 million euros, with 180,028 employees.

[Table 1 near here]

As discussed above, the indirect effect is divided into two: indirect first-order and indirect second-order effect. Table 2 shows the first-order indirect effects obtained. 
Taking into account all the purchases of goods and services (and investments) made by the MoD and AA, we could conclude that such purchases of goods and services finally led, in 2010, to an increase in the country's production of 3,849 million euros, a GVA of 1,884 million euros and 35,468 jobs.

[Table 2 near here]

Once the results of the estimation of the first-order indirect impact have been shown, it is interesting to know, at a sector level, which are the main sectors that have benefited from the purchases and investments. Figure 4 shows the sectors that benefit most from the first-order indirect effects. The three most benefiting sectors are: wholesale and intermediaries, other business activities, and insurance and pension plans. Note that the ten most benefiting sectors gain approximately $80 \%$ of the total first-order indirect effects.

[Figure 4 near here]

After the first-order indirect effects, a linkage effect occurs with other sectors of the economy due to existing sectoral relations. This linkage effect is called second-order indirect effect and is shown in Table 3 .

Taking together all the purchases of goods and services (and investments), we conclude that such acquisitions in 2010 generated an increase in the country's production of 2,832 million euros, a GVA of 1,243 million and employed 18,707 people.

[Table 3 near here] 
Figure 5 shows the ten sectors most benefiting from the indirect effects of the second order. The five most benefiting sectors are: construction, other business activities, ancillary activities, real estate activities, and post and telecommunications. Note that the ten most benefiting sectors gained around $60 \%$ of total indirect effects of the second order.

[Figure 5 near here]

The results of induced impact (see Table 4) show that the induced effects increased production by 7,806 million euros, the GVA by 3,947 million euros and employed 75,812 people.

[Table 4 near here]

Once the direct, indirect and induced effects had been estimated, we proceeded to calculate the total effects as the sum of the previous three in terms of production, GVA and total employment generated. In Table 5 these results are shown: a total production of 23,847 million euros, total GVA generated 12,111 million euros, and a total employment of 310,015 people.

[Table 5 near here]

With the aim of better interpreting the results, we calculate the GVA generated in relation to the GDP of Spain in 2010. Similarly, the number of generated jobs is relativized by the total number of employed in Spain. Table 6 shows the results. If only considering the direct effect, the central authority of the MoD contributed $0.14 \%$ of the 
country's GDP in 2010 and $0.2 \%$ in employment. If the indirect and induced effects are also considered, the contribution amounts to $0.32 \%$ in terms of GDP and $0.39 \%$ in terms of employment. In the case of the armed forces, the direct impact is quantified in a contribution to GDP of $0.32 \%$ and $0.76 \%$ employment, whereas when considering the total impact, these percentages are $0.67 \%$ and $1.14 \%$ respectively. Taking together the central authority and the armed forces, a direct contribution to GDP of $0.46 \%$ and $0.96 \%$ for employment is obtained. When you also add the indirect and induced effects, these percentages increase to $0.99 \%$ of GDP and $1.53 \%$ of employment.

In relation to all AA, their direct contribution to GDP is $0.024 \%$ and $0.016 \%$ employment (without regard to direct employment of the National Intelligence Centre (CNI), for which information is not available). In terms of total impact, their contribution to GDP is $0.17 \%$, and $0.15 \%$ to the country's employment. If the results of the MoD and the AA are added, we find that their direct contribution to GDP is $0.48 \%$ and $0.98 \%$ employment. The overall effect - including direct, indirect and induced effects - of MoD and AA contributed $1.16 \%$ to the 2010 GDP and $1.68 \%$ to total employment.

[Table 6 near here]

Finally, the tax revenue generated by the activities of MoD and AA is shown in Table 7. Tax revenue generated by the total activity (direct, indirect and induced effects) of the central authority amounted to 1,043 million euros (553 million VAT, 140 million corporate tax and 350 million personal income tax). For the armed forces, the revenue is 2,138 million euros (1,087 million VAT, 295 million corporate tax and 756 million personal income tax). By adding the results of the central authority and the armed 
forces, the revenue amounted to 3,181 million euros (1,640 million VAT, 435 million corporate tax and 1,106 million personal income tax). When the AA is considered, total tax revenue is 710 million (451 million VAT, 117 million corporate tax and 142 million personal income tax). If these results are added it can be concluded that the activities of the MoD and AA have generated 3,891 million euros of total tax revenue (2,091 million VAT, 552 million corporation tax and 1,248 million income tax).

[Table 7 near here]

\section{Conclusions}

The aim of this study is to quantify the economic impact of the activity of the MoD and AA on the Spanish Economy in 2010. This impact exceeds the MoD's own expenses and its estimation is particularly relevant at a time of crisis in which government spending will be frozen or even reduce.

When the economic impact of the activity conducted by an economic agent (a company, or a public institution as is the case in this article) is analysed, not only must the direct impact discussed in terms of production or workers be taken into account. The activity of the MoD also leads to increased production and employment in the provider sectors. Thus, as a result of the initial impulse application by the MoD as a whole, a complex network of intersectoral relationships is triggered, resulting in a multiplier effect on all sectors of the economy (indirect effect). This impact has been quantified and its distribution shows that the sectors that benefit the most are 'construction', 'other business activities' and 'wholesale trade and commission'. The economic impact, however, does not stop at the direct and indirect impact. In a second phase there appear 
so-called induced effects, arising from the economic stimulus produced by the consumption financed by the income generated from the direct and indirect effects. Therefore, our estimate of the economic impact takes into account three types of effect: direct, indirect, and induced.

Using information from the 2010 budgets of the various organs (plus other information), and through the application of input-output methodology, the total impact in terms of three basic variables - production, employment and GVA - has been estimated. In turn, and in order to quantify the actual contribution to the economy, GVA and the number of employees generated by the MoD and AA have been relativized to the GDP and total employment in 2010. Finally, we estimated tax revenue derived from the total economic impact of the activity of $\mathrm{MoD}$ and AA (in terms of income tax, VAT and corporation $\operatorname{tax})$.

Given the importance of obtaining relevant information, we have chosen the year 2010 for the analysis as it was the last year for which complete and consolidated data were available. It would be interesting to perform this analysis for other years and to compare the evaluations produced. This would allow additional conclusions. However, this has not been possible due to the high cost of obtaining required information, and it is thought that the presentation of the estimates presented for 2010 is already very relevant in itself. It is a line of future research that can be pursued when there is enough information for a more recent year.

The main results can be summarized as follows. After adding the results, we conclude that from an initial production of 9,359 million euros, direct GVA of 5,036 million and 
180,028 direct employed (excluding National Intelligence Centre), the activity of the MoD and AA ended up generating an extra 7,075 million in GVA, with an additional 129,987 employed in almost all sectors of the economy.

Thus, in total 12,111 million euros GVA are generated (that supposes a multiplier of 2.4 and $1.16 \%$ of the country's GDP), and 310,015 employees (multiplier of 1.7 and $1.68 \%$ of total employment in the country). It can be concluded that for every 1,000 euros of spending in 2010, 1,294 euros of GDP were generated, and for every 100 directly employed, 72 additional jobs were generated in the Spanish Economy. ${ }^{8}$ In turn, 1,000 euros of expenditure accounted for a tax revenue of 416 euros (in terms of VAT, income tax and corporation tax).

\section{Acknowledgements}

We are grateful to Ministry of Defence of Spain for their support and for providing the data needed to conduct this research.

This work was supported by the Spanish Ministry of Education and Science, under the project ECO2013-41022-R.

\section{References}

Alptekin, A. and Levine, P. (2012) "Military expenditure and economic growth: A metaanalysis." European Journal of Political Economy, 28(4), 636-650.

AMEC Earth \& Environmental y Gardner Pinfold Consulting Economists Ltd. (2004) Economic Impact of Military Flight Training in Labrador and Northeastern Quebec. Institute for Environmental Monitoring and Research.

Andersson, L., Lundberg, J. and Sjöström, M. (2007) "Regional effects of military closures: The case of Sweden." Defence and Peace Economics, 18(1), 87-97.

BBPC (2009) Massachusetts Military Reservation Economic Impact Study. Basile Baumann, Prost, Cole \& Associates, Inc.

\footnotetext{
${ }^{8}$ This calculation does not account for direct employment by the CNI
} 
Bernauer, T., Koubi, V. and Ernst, F. (2009) "National and regional economic consequences of Swiss defense spending." Journal of Peace Research, 46(4), 467-484.

Brockett, S.R., Cooper, A., Gauland, D.J. and Francisco, R. (2004) North Carolina Statewide Military Impact Study. North Carolina Advisory Commission on Military Affairs.

Chan, S. and Clark, C. (1990) "Can good things go together? A virtuous cycle in East Asia.” International Studies Notes, 15(1), 4-9.

Chiappe, J. (2011) Oklahoma's Five Military Installations: An Economic Impact Report. Oklahoma 21st Century Foundation \& Oklahoma Department of Commerce.

Cowan, T. and Gonzales, O.R. (2011) Military Base Closures: Socioeconomic Impacts. Congressional Research Service, CRS Report for Congress, RS22147.

Cowan, T. and Webel, B. (2005) Military base closure: Socioeconomic Impacts. Washington, DC: Congressional Research Service, CRS Report.

Deloitte Touche Tohmatsu Ltd. (2012) The Economic Impact of the NATO Summit on the City of Chicago. Deloitte Development LLC.

Dunne, J.P., Smith, R.P. and Willenbockel, D. (2005) "Models of military expenditure and growth: A critical review." Defence and Peace Economics, 16(6), 449-461.

Dunne, J.P. and Tian, N. (2013) "Military expenditure and economic growth: A survey." Economics of Peace and Security Journal, 8(1), 5-11.

Dunne J.P. and Uye, M. (2010) "Military spending and development." In: A. Tan (Ed.) The Global Arms Trade: A Handbook. Routledge, pp. 293-305.

EPS (2007) Economic Impact Analysis of Delayed Military Base Reuse in California. Economic \& Planning Systems, Inc. EPS White Paper 17002.

Erdogdu, O.S. (2008) "Political decisions, defence and growth." Defence and Peace Economics, 19(1), 27-35.

Feridun, M., Sawhney, B. and Shahbaz, M. (2011) "The impact of military spending on economic growth: The case of North Cyprus." Defense and Peace Economics, 22(5), 555-562.

Feridun, M. and Sezgin, S. (2008) "Regional underdevelopment and terrorism: The case of south eastern Turkey." Defence and Peace Economics, 19(3), 225-233.

Hamsik, B. and Moore, C. (2011) San Diego Military Economic Impact Study. San Diego Military Advisory Council.

Hartley, K. (2010) “The case for defence.” Defence and Peace Economics, 21(5-6), 409-426.

Heo, Uk., (2010). "The relationship between defense spending and economic growth in the United States.” Political Research Quarterly, 63 (4): 760-770.

Heo, Uk. and Hahm, S.D. (2006) "Politics, Economics, and Defense Spending in South Korea." Armed Forces \& Society, 32(4), 604-622. 
Hill, J. (2009) Kansas Military Analysis. Fiscal and Economic Impact of Military Activity in Kansas. Wichita State University Research Report.

Hultquist, A. and Petras, T.L. (2012) "An examination of the local economic impacts of military base closures.” Economic Development Quarterly, 26(2), 151-161.

Hunter, S. (2009) Military Presence and Economic Significance in the South West Region. Policy and Research, Wiltshire Council.

INE. Clasificación Nacional de Actividades Económicas (1993) Rev.1. (Accessed June 2013) http://www.ine.es/clasifi/cnae93rev1.pdf

INE. Nota metodológica sobre las tablas simétricas de la economía española en base 2000. (Accessed June 2013) Retrieved from: http://www.ine.es/daco/daco42/cne00/simetrica2005.pdf

INE. Correspondencias de la tabla simétrica input-output (TSIO) con la CNAE/CNPA (Accessed June 2013) Retrieved from:

http://www.ine.es/jaxi/menu.do?type $=$ pcaxis $\&$ path $=\% 2 \mathrm{Ft} 35 / \mathrm{p} 008 \&$ file $=$ inebase $\& \mathrm{~L}=0$

INE. Contabilidad Nacional de España. Tablas de origen y de destino. (Accessed June 2013) Retrieved from:

http://www.ine.es/jaxi/menu.do?type=pcaxis $\&$ path $=\% 2 \mathrm{Ft} 35 / \mathrm{p} 008 \&$ file $=$ inebase $\& \mathrm{~L}=0$

Jaffry, S., Clark, D. and Asteris, M. (2012) Socio-Economic Impact Assessment of Portsmouth Naval Base. The Partnership for Urban South Hampshire and Solent Local Enterprise Partnership.

KPMG (2012) Economic Impact of the Defence and Security Industry in Canada. Canadian Association of Defence and Security Industries.

Lahr, M.L. (2004) The Economic Contribution of Military and Coast Guard Installations to the State of New Jersey. Rutgers University: Center for Urban Policy Research.

Maguire Company and ESI Corporation (2008) Economic Impact of Arizona's Principal Military Operations. Arizona Department of Commerce.

Martí-Sempere, C. (2011) "The European security industry. A research agenda." Defence and Peace Economics, 22(2), 245-264.

Ministerio De Defensa (2010) Presupuesto del Ministerio de Defensa. Año 2010. Secretaría de General Técnica. Ministerio de Defensa.

Nienow, S., Harder, C., Cole, T. and Lea, A. (2008) North Carolina's Military Footprint: Current Economic Impacts and Projections for 2013. North Carolina Advisory Commission on Military Affairs.

Nijhawan, I. and Jackson, P. (2008) "Economic impact of base realignment and closing on the Fort Bragg region and the largest army base in the United States." Proceedings of the Academy for Economics and Economic Education, 13(2), 12-15.

Nivin, S. and Birdwell, M. (2006) Economic Impact of the US Department of Defense in San Antonio. Office of Military Affairs (OMA). 
Paloyo, A.R., Vance, C. and Vorell, M. (2010) "The regional economic effects of military base realignments and closures in Germany." Defence and Peace Economics, 21(5-6), 567-579.

Safdari, M., Keramati, J. and Mahmoodi, M. (2011) "Relationship between military expenditure and economic growth in four Asian countries." Chinese Business Review, $10(2), 112-118$.

Schauer, D.A. et. al. (2004a) Economic Impact of Holloman Air Force Base (HAFB) on the Regional Economy. IPED Technical Reports, Institute for Policy and Economic Development.

Schauer, D.A. et. al. (2004b) 2002 Economic Impact of White Sands Missile Range (WSMR) on the Regional Economy. IPED Technical Reports, Institute for Policy and Economic Development.

Smith, R.P. (2000) "Defence expenditure and economic growth." In: N.P. Gleditsch, G. Lindgren, N. Mouhleb, S. Smith and I. de Soysa (Eds.) Making Peace Pay: A Bibliography on Disarmament and Conversion. Laremont: Regina Books, pp. 15-24.

Soden, D.L., Schauer, D.A. and Conary, J.S. (2005) "Military installations in regional economies: The impacts of three bases in the Paso Del Norte Region." Applied Research in Economic Development, 2(2), 65-83.

Sommers, P. (2004) Economic Impacts of Military Bases in Washington. Washington State Office of Financial Management.

Stehlik, D., Jennings, G. and Dwyer, L. (2004) A Socio-Economic Impact Study Of Defense Force Activity in Central Queensland Australia. The Commonwealth Department of Defense.

Thanner, M.H. and Segal, M.W. (2008) "When the military leaves and places change: Effects of the closing of an army post on the local community." Armed Forces and Society, 34(4), 662681.

Wanga, T.-P., Shyub, S.H.-P. and Chouc, H.-CH. (2012) "The impact of defense expenditure on economic productivity in OECD countries." Economic Modelling, 29(6), 2104-2114.

Weinstein, B.L. and Clower, T.L. (2004) The Economic and Fiscal Impacts of Armed Forces Exchange Service Realignment on Dallas County and the City of Dallas. Center for Economic Development and Research. University of North Texas.

Wijeweera, A. and Webb, M.J. (2011) "Military spending and economic growth in South Asia: A panel data analysis." Defence and Peace Economics, 22(5), 545-554. 


\section{Tables}

Table 1. Direct impact totals, 2010

\begin{tabular}{|c|c|c|c|c|c|}
\hline & $\begin{array}{r}\text { Central } \\
\text { Authority }^{(I)}\end{array}$ & $\begin{array}{r}\text { Armed } \\
\text { Forces }\end{array}$ & $\begin{array}{r}\text { MoD } \\
(\text { I + II = III) }\end{array}$ & $\mathbf{A} \mathbf{A}^{(\mathbf{I V})}$ & $\begin{array}{r}\text { TOTAL } \\
(\text { III + IV })\end{array}$ \\
\hline Production (000's $€$ ) & $2,842,231$ & $5,016,686$ & $7,858,917$ & $1,500,052$ & $9,358,969$ \\
\hline Occupied $^{(1)}$ & 36,964 & 140,176 & 177,140 & 2,888 & 180,028 \\
\hline GVA (000's €) & $1,447,580$ & $3,334,523$ & $4,782,103$ & 253,678 & $5,035,781$ \\
\hline
\end{tabular}

Table 2. First order indirect impact totals, 2010

\begin{tabular}{|c|c|c|c|c|c|}
\hline & $\begin{array}{l}\text { Central } \\
\text { Authority }^{(\mathrm{I})}\end{array}$ & $\begin{array}{r}\text { Armed } \\
\text { Forces }\end{array}$ & $\begin{array}{r}\text { MoD } \\
(\text { I + II = III) }\end{array}$ & $\mathbf{A} \mathbf{A}^{(\mathbf{I V})}$ & $\begin{array}{r}\text { TOTAL } \\
(\text { III + IV })\end{array}$ \\
\hline Production (000's €) & 955,635 & $1,653,366$ & $2,609,001$ & $1,240,581$ & $3,849,582$ \\
\hline Occupied $^{(1)}$ & 8,703 & 15,820 & 24,523 & 10,945 & 35,468 \\
\hline GVA (000’s €) & 458,861 & 815,883 & $1,274,744$ & 609,607 & $1,884,351$ \\
\hline
\end{tabular}


Table 3. Second order indirect impact totals, 2010

\begin{tabular}{|c|c|c|c|c|c|}
\hline & $\begin{array}{r}\text { Central } \\
\text { Authority }^{(I)}\end{array}$ & $\begin{array}{r}\text { Armed } \\
\text { Forces (II) }\end{array}$ & $\begin{array}{r}\text { MoD } \\
(\text { I + II = III) }\end{array}$ & $\mathbf{A} \mathbf{A}^{(\mathbf{I V})}$ & $\begin{array}{r}\text { TOTAL } \\
\text { (III + IV) }\end{array}$ \\
\hline Production (000's $€$ ) & 686,477 & $1,197,851$ & $1,884,328$ & 947,899 & $2,832,227$ \\
\hline Occupied $^{(1)}$ & 4,617 & 7,815 & 12,432 & 6,275 & 18,707 \\
\hline GVA (000's €) & 291,707 & 510,653 & 802,360 & 441,020 & $1,243,380$ \\
\hline
\end{tabular}

Table 4. Induced Economic Impact, 2010

\begin{tabular}{|c|c|c|c|c|c|}
\hline & $\begin{array}{r}\text { Central } \\
\text { Authority }^{(\mathrm{I})}\end{array}$ & $\begin{array}{r}\text { Armed } \\
\text { Forces }\end{array}$ & $\begin{array}{r}\text { MoD } \\
(\mathrm{I}+\mathrm{II}=\mathrm{III})\end{array}$ & $\mathbf{A} \mathbf{A}^{(\mathbf{I V})}$ & $\begin{array}{r}\text { TOTAL } \\
\text { (III + IV) }\end{array}$ \\
\hline Production (000's $€$ ) & $2,202,293$ & $4,750,462$ & $6,952,755$ & 853,294 & $7,806,049$ \\
\hline Occupied $^{(1)}$ & 21,388 & 46,137 & 67,525 & 8,287 & 75,812 \\
\hline GVA (000's €) & $1,113,619$ & $2,402,134$ & $3,515,753$ & 431,486 & $3,947,239$ \\
\hline $\begin{array}{l}\text { Note: }{ }^{(1)} \text { No informatic } \\
\text { Ministry and the Gene } \\
\text { Air Force; (III) Central } \\
\text { elaboration }\end{array}$ & $\begin{array}{l}\text { lable on the } n \\
\text { f the Defence } \\
\text { ty and Armec }\end{array}$ & $\begin{array}{l}\text { ber emplos } \\
\text { d the Min } \\
\text { orces; (IV) }\end{array}$ & $\begin{array}{l}\text { d by CNI. } \\
\text { ry of Defe } \\
\text { ggregation }\end{array}$ & $\begin{array}{l}\text { ote: }{ }^{(\text {I) }} \mathrm{U} \\
\text { e; }{ }^{\text {(II) }} \mathrm{Arn} \\
\text { of AA. }\end{array}$ & $\begin{array}{l}\text { lersecretary } \\
\text {, Navy and } \\
\text { urce: Own }\end{array}$ \\
\hline
\end{tabular}


Table 5. Total Impact, MoD and AA, 2010

\begin{tabular}{lrrrr}
\hline & Direct & Indirect & Induced & Total \\
& Effect & Effect $^{(\mathbf{1})}$ & Effect & Effect \\
\hline Production (000's $\boldsymbol{\Theta})$ & $9,358,969$ & $6,681,809$ & $7,806,049$ & $23,846,827$ \\
Occupied $^{(2)}$ & 180,028 & 54,175 & 75,812 & 310,015 \\
GVA (000's $\boldsymbol{\Theta})$ & $5,035,781$ & $3,127,731$ & $3,947,239$ & $12,110,751$ \\
\hline
\end{tabular}

Notes: ${ }^{(1)}$ Total indirect effect of first and second order. ${ }^{(2)}$ The number of employees does not include direct CNI employed. Source: Own elaboration

Table 6. Contribution of total impact generated, 2010

\begin{tabular}{lcccr}
\hline & \multicolumn{2}{c}{ Contribution to } & \multicolumn{2}{c}{ Contribution to total } \\
& \multicolumn{1}{c}{ GDP (*) (Spain) } & employment (Spain) \\
\hline & Direct & Total & Direct & Total \\
& Effect & Effect & Effect & Effect \\
\hline Central Authority $^{(\mathbf{1})}$ & $0.14 \%$ & $0.32 \%$ & $0.20 \%$ & $0.39 \%$ \\
Armed Forces $^{(2)}$ & $0.32 \%$ & $0.67 \%$ & $0.76 \%$ & $1.14 \%$ \\
\hline MoD $^{(3=1+2)}$ & $0.46 \%$ & $0.99 \%$ & $0.96 \%$ & $1.53 \%$ \\
AA $^{(4)}$ & $0.02 \%$ & $0.17 \%$ & $0.02 \%$ & $0.15 \%$ \\
\hline TOTAL $^{(5=3+4)}$ & $0.48 \%$ & $1.16 \%$ & $0.98 \%$ & $1.68 \%$ \\
\hline
\end{tabular}

Note: (1) Secretariat and Ministry, the General Staff of the Defence and Ministry of Defence. (2) Army, Navy and Air Force. (3) Central Authority and Total Army. (4) Does not consider the number of direct CNI employed as information unavailable. (*) Calculated from data of direct and total GVA generated. Source: Own elaboration

Table 7. Effects derivatives in terms of tax revenue, 2010 (000's euros) 


\begin{tabular}{lrrrr}
\hline & VAT & Corporate Tax & Income Tax & TOTAL \\
\hline Central Authority $^{(\mathbf{1})}$ & 552,840 & 140,101 & 350,324 & $1,043,265$ \\
Armed Forces $^{(2)}$ & $1,087,114$ & 295,169 & 755,663 & $2,137,946$ \\
MoD $^{(3)}$ & $1,639,954$ & 435,270 & $1,105,987$ & $3,181,211$ \\
AA & 450,982 & 117,080 & 141,914 & 709,976 \\
TOTAL & $\mathbf{2 , 0 9 0 , 9 3 6}$ & $\mathbf{5 5 2 , 3 5 0}$ & $\mathbf{1 , 2 4 7 , 9 0 1}$ & $\mathbf{3 , 8 9 1 , 1 8 7}$ \\
\hline
\end{tabular}

Note: (1) Secretariat and Ministry, the General Staff of the Defence and Ministry of Defence.

(2) Army, Navy and Air Force. (3) Central Authority and Total Army. Source: Own elaboration 


\section{Figures}

Figure 1. Effects arising from the activities of Mod and AA

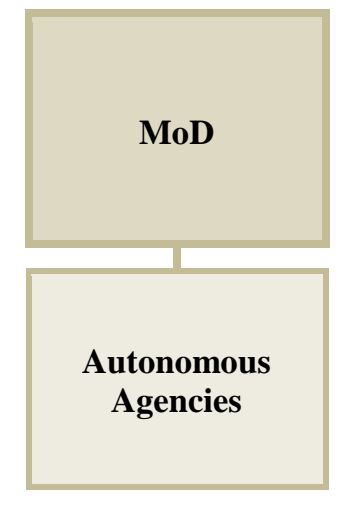

Policies of MoD:

- Defence

- Health Service

- R\&D\&I

- Culture

- Financial and Tax Administration

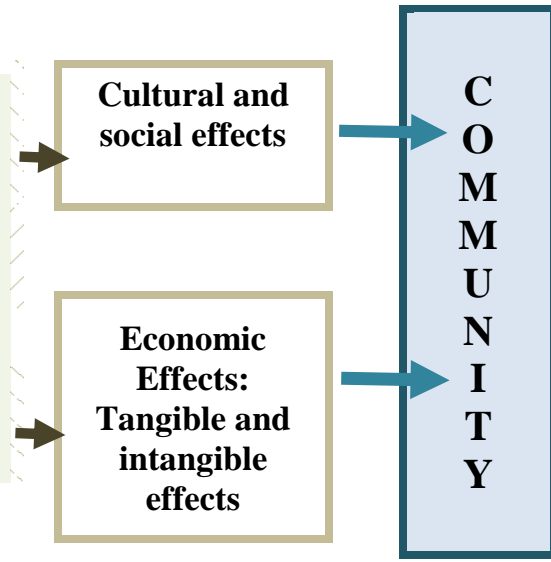

Source: Authors

Figure 2. Effects considered in the estimation of economic impact of MoD

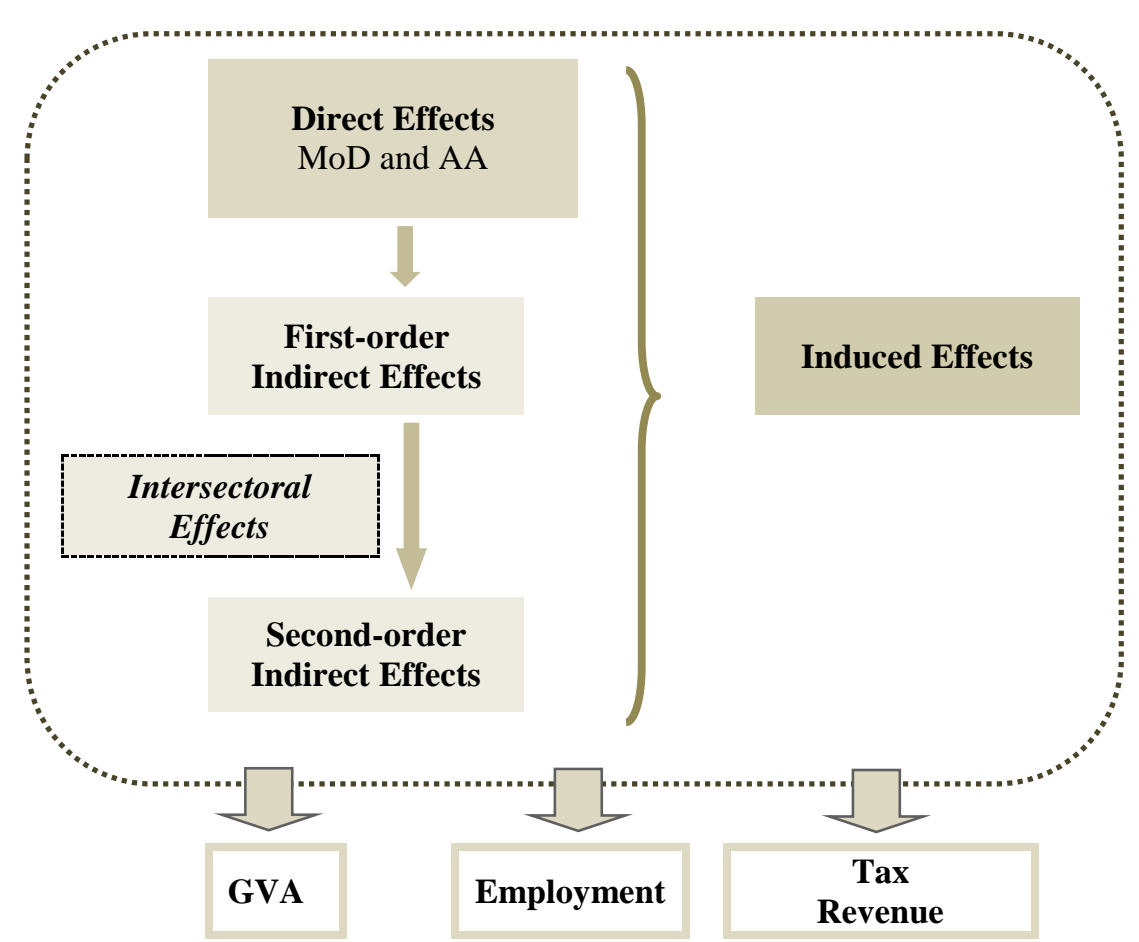

Source: Authors 
Figure 3. Stages in the estimation of the final economic impact of MoD and AA Stage one: Calculation of the direct effect

Objective of the stage
$\begin{aligned} & \text { - To determine the amount and structure of } \\ & \text { direct expenditure by MoD and AA. }\end{aligned}$

\begin{tabular}{lr}
\hline \multicolumn{2}{|c}{ Stage two: Calculation of the indirect effects } \\
\hline Objectives of the stage & Steps \\
\hline
\end{tabular}

- To identify the intersectoral (indirect) effects of $\mathrm{MoD}$ and AA activity on other economic sectors.

- To identify the territorial area in which the indirect effects arise.
To identify the intersectoral multiplier effects of the economic stimulus generated by MoD and AA direct spending using input-output methodology.

To establish the location of the suppliers of $\mathrm{MoD}$, in order to identify the territorial area in which the economic effects occur. We consider only one area, national territory.

\begin{tabular}{ll} 
Stage three: Calculation of induced effects \\
\hline Objectives of the stage
\end{tabular}

- To determine the employees' earnings generated as a result of the direct and indirect effects of MoD and AA activities.

- To assess the proportion of those earnings that are ultimately destined for the consumption of goods and services.

Source: Authors
To calculate the labour income generated directly or indirectly by MoD and AA.

To determine the structure of household budgets in order to deduct the portion of labour income that goes into tax, acquisitions of goods and services from outside the country, and savings. 


\section{Figure 4. Sectors most benefiting from first-order indirect impact on output generated by the MoD and AA}

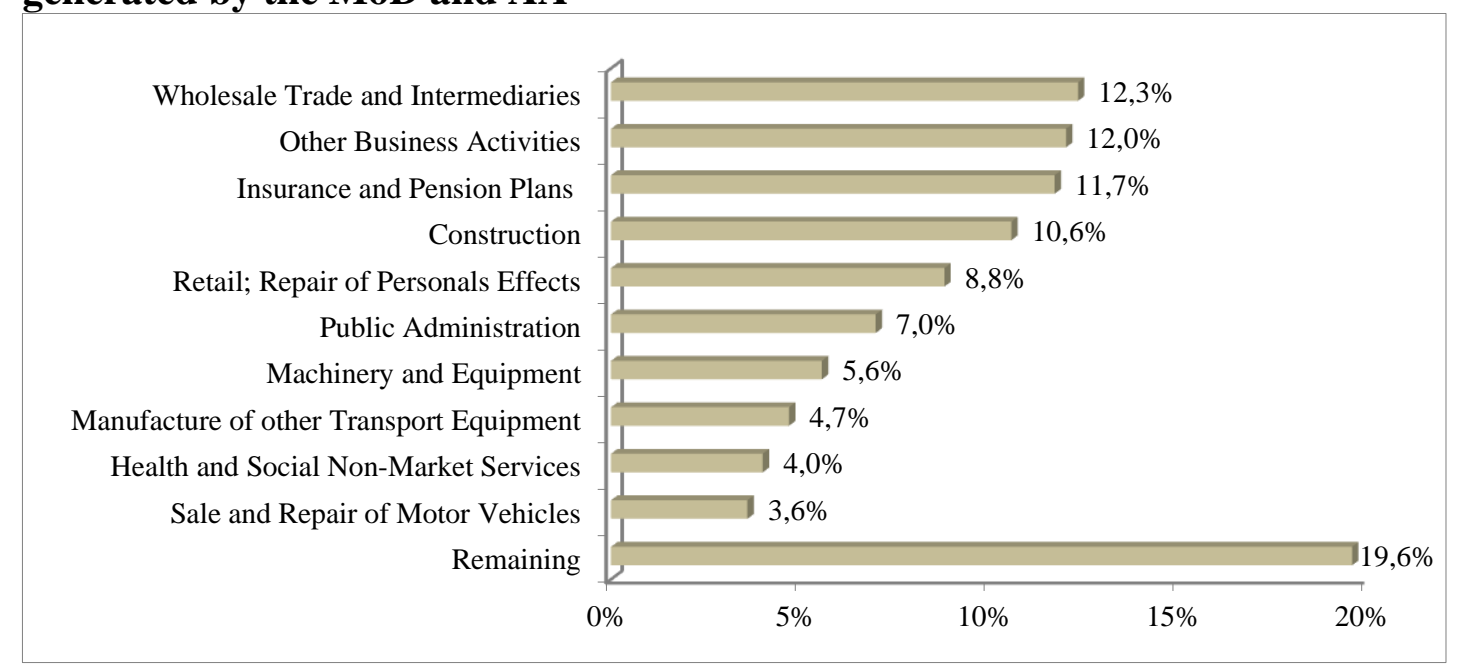

Source: Own elaboration

Figure 5. Sectors most benefiting from second-order indirect impact on output generated by the MoD and AA

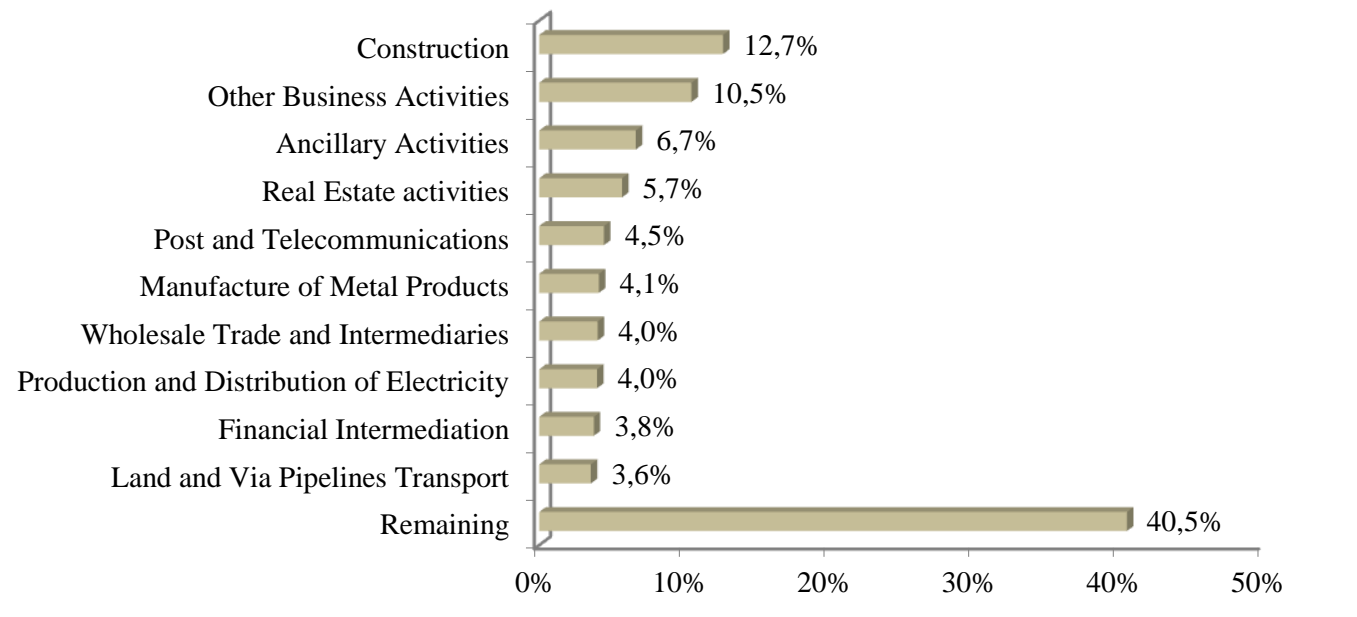

Source: Own elaboration 